IZA DP No. 7395

Digital Labor-Market Intermediation and Job Expectations:

Evidence from a Field Experiment

Ana C. Dammert

Jose C. Galdo

Virgilio Galdo

May 2013 


\title{
Digital Labor-Market Intermediation and Job Expectations: Evidence from a Field Experiment
}

\author{
Ana C. Dammert \\ Carleton University and IZA
}

Jose C. Galdo

Carleton University and IZA

Virgilio Galdo

World Bank

\author{
Discussion Paper No. 7395 \\ May 2013
}

IZA
P.O. Box 7240
53072 Bonn
Germany

Phone: +49-228-3894-0

Fax: +49-228-3894-180

E-mail: iza@iza.org

\begin{abstract}
Any opinions expressed here are those of the author(s) and not those of IZA. Research published in this series may include views on policy, but the institute itself takes no institutional policy positions. The IZA research network is committed to the IZA Guiding Principles of Research Integrity.

The Institute for the Study of Labor (IZA) in Bonn is a local and virtual international research center and a place of communication between science, politics and business. IZA is an independent nonprofit organization supported by Deutsche Post Foundation. The center is associated with the University of Bonn and offers a stimulating research environment through its international network, workshops and conferences, data service, project support, research visits and doctoral program. IZA engages in (i) original and internationally competitive research in all fields of labor economics, (ii) development of policy concepts, and (iii) dissemination of research results and concepts to the interested public.
\end{abstract}

IZA Discussion Papers often represent preliminary work and are circulated to encourage discussion. Citation of such a paper should account for its provisional character. A revised version may be available directly from the author. 


\section{ABSTRACT}

\section{Digital Labor-Market Intermediation and Job Expectations: Evidence from a Field Experiment}

Subjective expectations are fundamental for understanding individual behavior. Yet, little is known about how individuals use new information to formulate and update their subjective expectations. In this study, we exploit data from a multi-treatment field experiment to investigate how job-market information sent to jobseekers via short text messages (SMS) influence subjective job gain expectations in Peru. Results show that jobseekers who received digital intermediation based on a large information set increased their before-after job gain expectations relative to the control group. Independently of the information channel, no significant effects were found when labor-market intermediation is based on a restricted (short) set of information.

JEL Classification: $13, \mathrm{~J} 2$

Keywords: subjective expectations, labor-market intermediation, ICT, field experiments, Peru

Corresponding author:

Virgilio Galdo

World Bank

1818 H Street, NW

Washington, DC 20433

USA

E-mail: vgaldo@worldbank.org

\footnotetext{
* We acknowledge financial support from the Inter-American Development Bank (IADB) and the Social Sciences and Humanities Research Council of Canada (SSHRC). We thank Chris Worswick and Alberto Chong for valuable comments and suggestions. We also thank SASE Asociación Civil and the Ministry of Labor and Social Promotion of Peru for their logistic and institutional support. Rene Castro and Minoru Higa provided excellent research assistance. The standard disclaimer applies.
} 


\section{Introduction}

Understanding of the role of subjective expectations on economic behavior is central for economic modelling and policy design. While most progress in expectations literature pertains to its influence on a number of economic outcomes (see the surveys in Manski 2004 and Delavande et al. 2011), little is known about how individuals use available information to formulate and update their subjective expectations. In fact, few studies have directly addressed the role of information on the formation of expectations (e.g., Luseno et al. 2003, Jensen 2010, and Stinebricker et al. 2012).

In the last decade, Information and Communication Technologies (ICT) have expanded at unprecedented rates in both developed and developing economies. In contrast to the Internet, mobile phones have become the most rapidly adopted technology in developing countries (Chong 2010). Mobile phones allow information to travel instantly and at lower costs. Not surprisingly, a small but growing body of empirical literature has credited mobile phones with reductions in transaction costs and efficiency gains in developing settings (e.g., Jensen 2007, Aker 2010, and Goyal 2010). So far, however, no study has addressed the link between digital information and subjective expectations.

This paper bridges these two streams of literature by investigating how information about job-market opportunities sent to jobseekers via short text messages (SMS) influence subjective expectations. By providing faster, better, and cheaper access to information, mobile phone technologies might influence job gain expectations, as searchers can access relevant, up-to-date information on job vacancies. From a theoretical perspective, job decisions are forward-looking and thus involve expectations. For instance, sequential search models that incorporate uncertainty about the wage distribution are based on expectations that depend on information 
signals coming from the wage offers individuals observe during their search time (e.g., Diagne 2010).

As expectations could be merely proxying for other unobserved characteristics, a distinctive feature of this study is its field experimental design with multiple treatments. We use data from the Public Intermediation System in Peru, a country that adopted an innovative egovernment initiative in labor intermediation. Searchers that signed up to receive public labormarket intermediation were randomly assigned to four treatment groups according to two information channels (i.e., digital and non-digital intermediation) and the scope of information they received (i.e., short [public] and enhanced [public/private] information sets).

This study finds that jobseekers subject to digital labor-market intermediation based on a large set of information show a positive and statistically significant change in their job gain expectations three months after signing up for public labor-market intermediation. This result suggests that the combination of digital technology and the scope of the information set matters rather than the technology by itself.

\section{The Intervention: Institutions, Treatment, and Data}

The experimental design was implemented as part of the regular (non-experimental) public intermediation system CIL-PROEMPLEO, which is run nationally for the Ministry of Labor in Peru and offers intermediation services, electronic information on the labor markets, and low-cost reemployment services to jobseekers who voluntarily sign up for these services. ${ }^{1}$ CIL-PROEMPLEO aims to ease the labor-market functioning by decreasing search costs and

\footnotetext{
${ }^{1}$ Unlike western developed economies, Peru does not have an Unemployment Insurance (UI) system. Thus, participation in SIL-PROEMPLEO is voluntary and unrelated to UI benefit reception.
} 
improving the quality of employer/worker matches. ${ }^{2}$ Since its introduction in 1998, the proportion of unemployed people in Peru who use the public intermediation program has increased substantially from 3 percent in 1997 to 18 percent in 2010 (Ministry of Labor 2012).

The treatment consisted of three months of subsidized job search assistance in which individuals' labor profiles were matched with available job vacancies. The experimental sample was selected at the initial registration filing for the normal inflow of applicants in Lima after excluding registered individuals who do not own mobile phones or hold occupations with very high turnover rates; i.e., unskilled peons. The random assignment was carried out on a daily basis (excluding weekends and holidays) from June 22, 2009, to September 1, 2009. In total, 1,280 job seekers were randomly allocated to one of four different groups: (1) short-non-digital treatment group, (2) short-digital treatment group, (3) enhanced-digital treatment group, and (4) a control group, following a random allocation of 30, 15, 25, and 30 percent, respectively. In total, 40 percent of the sample was subject to digital labor-market intermediation.

The short-non-digital treatment group was subject to the standard CIL-PROEMPLEO intermediation practices. In contrast to this treatment group, the digital treatment groups 2 and 3 were exposed to a technological innovation aimed to reduce job search costs. Jobseekers assigned to these groups were informed about job-market opportunities that match their labor profile through digital services; i.e., delivery of SMS messages to their mobile phones. The difference between treatment groups 2 and 3 is given by the set of information available to them. According to CIL-PROEMPLEO regulations, job matches are based only on firms that signed up on the public intermediation system. Treatment group 3 relaxed this restriction by considering an

\footnotetext{
${ }^{2}$ Labor-market intermediaries are institutions that somehow interpose themselves in the employer-worker relationship to ease the functioning of the labor markets. Yet, despite their potential contribution to the functioning of the labor market, they remain relatively understudied (Autor 2001).
} 
enhanced set of information coming from job opportunities generated outside the CILPROEMPLEO system (e.g., job boards, national newspapers ads, and non-profit private employment agencies). ${ }^{3}$ Independently of whether individuals belong to the short- or enhanceddigital treatment groups, the framing of the information sent to jobseekers via SMS follows a standard structure and is limited to the description of the occupation and contact information. ${ }^{4}$ Finally, control group individuals were removed temporarily from the information system for a period of three months. ${ }^{5}$

Comparison of treatment groups 2 and 3 allows one to test the impact of expanding the set of information available to jobseekers while holding fixed the information technology. From a theoretical standpoint, however, more information does not automatically lead the updating of subjective (job) expectations. Information theory states that if individuals update their expectations (or change their behavior) in response to new information they receive, then that information has value to them. According to Hirshleifer and Riley (1992), the value of information is determined by three important factors-confidence, novelty, and ability and willingness to act based on updated beliefs—all of which involve different forces and trade-offs. Individuals process new information largely based on their prior beliefs. If job seekers, for instance, place strong confidence in their initial beliefs, more information is not necessarily more valuable, all else held constant. Evidence from behavioral economics, for instance, suggests that individuals who formulate their initial beliefs based on poor past experiences have difficulty interpreting subsequent new information, as initial expectations tend to anchor one's processing

\footnotetext{
${ }^{3}$ According to the 2003 survey of formal firms located in Metropolitan Lima, the advertisement of job vacancies is mainly done via newspaper ads (54 percent) and personal contacts (43 percent).

${ }^{4}$ A literal reproduction of an SMS message says: "PROEMPLEO. Hostess wanted Restaurant Amador Av. La Mar \#3453 Lince Tel 3038145. Contact: Elizabeth Bartra”.

${ }^{5}$ All individuals in the sample were unaware of both their participation in an experiment and the exogenous manipulation of the economic (intermediation) environment. This minimizes potential bias induced by the presence of 'John Henry' effects or, more generally, 'Hawthorne' effects (List and Rasul 2010).
} 
of information (Tversky and Kahneman, 1974), thus leading to the so-called 'cognitive confirmation bias', a state on which people tend to ignore new information altogether or misread it (Griffin and Tversky, 1992).

Moreover, the greater the confidence in the message, the greater its effect on the updating of the subjective probability distribution. In this regard, it is noteworthy to recall that public labor market intermediation systems are populated with individuals with chronic problems of employability (Autor, 2001). ${ }^{6}$ As such, they could have developed strong initial beliefs given their relatively poor experience in the marketplace, a genuine distrust of information coming from public sources, or both. If that is the case, they will not update mechanically their initial expectations in response to more information.

On the other hand, if new information constitutes a novelty relative to the individual's initial expectations, then one expects a strong updating effect. In our view, the distinctiveness between short [public] and enhanced [public/private] information sets involves a novelty factor since historically the (standard) public intermediation system has operated only with information from a limited group of (low-quality) firms. Finally, the value of the information also depends on individuals' ability and willingness to respond to the new information. In this regard, incentives and constraints affect how individuals react to information shocks. For instance, there are some mitigating concerns with regard to the effectiveness of digital information in developing countries due to the lack of human capital and language barriers between the users of the technology and the technology itself (Chong, 2010).

In all, the effect of more information on subjective expectations is ultimately an empirical question and depends on the relative strengths and forces of different attributes of information.

\footnotetext{
${ }^{6}$ The unemployment spells for users of the public intermediation system in Peru is two-fold higher than that for nonusers.
} 
From an empirical standpoint little is known about how individuals update their subjective expectations in real life in response to new information (see Manski, 2004; Delavande et al., 2011). Available evidence suggests that if individuals update expectations, they do it with a predictable bias towards optimism. In fact, empirical studies show that new valuable information is often read optimistically rather than objectively, since people underreact to negative information and overreact to positive information (e.g., Easterwood and Nutt, 1999; Hirshleifer and Shumway, 2003).

The baseline dataset contains information for 1,189 individuals, which implies an attrition rate of 7 percent relative to the original sampling design. ${ }^{7}$ Out of this data, 29, 16, and 25 percent correspond to treatment groups 1,2 , and 3, respectively, while the remaining 30 percent correspond to the control group. A critical step in the estimation of the causal treatment effects is an analysis of how effective the randomization was. Table 1 shows the mean baseline distribution for a large set of socio-demographic and labor- market variables across all treatment groups. Panel A shows that the average individual in our sample has completed high school education, is younger than 30 years old, and is single. There is a slight disproportion in the rate of enrollment by gender, as 55 percent of registered users are men. Only 30 percent of users have offspring, while one-fourth of them were not born in Lima. The p-value of F-test for the equality of means across all four randomised groups is above 0.05 for all variables except age.

Panels $\mathrm{B}$ and $\mathrm{C}$ show the mean distribution for baseline variables related to prior labor market experiences and ICT exposure. The data show that most individuals in the sample had previous job experience in the private sector, worked on average 35 hours per week, and earned 560 soles per month. Less than one-third of them had fringe benefits, including health insurance

\footnotetext{
${ }^{7}$ The rate of attrition was similar in all treatment groups and it is not statistically related to any particular sociodemographic variable.
} 
and pension plans. Moreover, most jobseekers have experience using mobile phones and the Internet in general, while around half of the sample has used these electronic gadgets for job search purposes. The p-value of the F-test for the equality of means is above 0.05 for all variables considered in these two panels.

Finally, Panel D shows the distribution of future job gain expectations. The baseline survey asks, “Are you optimistic you will find a job in the next three months?” with answers on a Likert scale of 'very optimistic', 'somewhat optimistic', 'only a little optimistic', or 'do not expect to find a job’. ${ }^{8}$ Almost 68 percent of job seekers were very optimistic, while 26 and 5 percent were somewhat and only a little optimistic, respectively. Surprisingly, almost no one expects not to find a job. The p-value of F-test for the equality of means is above 0.05 for all of these categories. In sum, the statistical analyses suggest that the sample of individuals assigned to all of the different groups were drawn from the same population.

\section{Empirical Framework and Results}

The estimation framework is based on a standard difference-in-difference approach:

$$
Y_{i t+1}-Y_{i t}=\beta_{0}+\beta_{1} D_{i}^{T_{1}}+\beta_{2} D_{i}^{T_{2}}+\beta_{3} D_{i}^{T 3}+X_{i t}{ }^{\prime} \beta_{4}+\varepsilon_{i t}
$$

where $Y_{i t+1}-Y_{i t}$, is the before-after change in subjective expectations. Both $Y_{i t+1}$ and $Y_{i t}$ are expressed in binary form, with 'very optimistic'=1 and ('somewhat optimistic', 'only a little optimistic', 'do not expect to find a job')=0. $D_{i}^{T 1}, D_{i}^{T 2}$ and $D_{i}^{T 3}$ denote treatment indicators for the experimental groups 1,2 , and 3 , respectively. The coefficients $\beta_{1}, \beta_{2}$, and $\beta_{3}$ represent intentto-treat parameters of interest. The base category is the control group. $X_{i t}$ denotes a rich set of

\footnotetext{
${ }^{8}$ Manski (2004) provides a detailed analysis of Likert scales with respect to more sophisticated subjective probabilities. Likert scales do not allow, for instance, for answers in a cardinal scale, and thus cannot be used to calculate the moments of a distribution of interest.
} 
baseline covariates, while $\varepsilon_{i t}$ is the error term. The estimation sample is based on individuals who remain unemployed before and after the treatment as the survey design elicited subjective expectations only from them.

Table 2 presents estimates from the parametric model (1). Our estimates provide evidence that the enhanced-digital treatment intervention is positive and statistically related to before-after changes in subjective job gain expectations. Consider the parametric estimates in column 1. Although the parameters of interest across all treatment groups show a positive sign, only treatment group 3 reports statistically significant increases on job expectations relative to control group individuals. The point estimates for $\beta_{3}$ reach 14 percentage points, or a 20 percent increase with respect to the baseline measure of job expectations. Controlling for a rich set of socio-demographic variables does little to change the estimates or their statistical significance, as is shown in column 2.

Because it is possible that previous labor-market experiences exert strong influence on future job expectations, in column 3 we also include a rich set of baseline labor-market characteristics. Results show a small increase in the magnitude of $\beta_{3}$ (17 percentage points), which is statistically different from zero at the 5 percent level. In fact, columns 2 and 3 in Table 2 show that all baseline socio-demographic and labor-market variables are not statistically related to the outcome of interest, which adds evidence of the balancing property of the experimental design. Finally, as searchers were randomly allocated to four different groups on a daily basis following the normal inflow of applicants, we have as many experimental sets as different days the experimental sampling lasted. We therefore included in column 4 a date fixed effects to control for intra-day variation in the treatment allocation. The point estimates show slight variation with respect to results depicted in columns 2 and 3. Clustered standard errors by 
date report statistically significant impacts at the 5 percent level for the enhanced-digital treatment group.

These results tell a consistent story: It is not the technology itself that causes a (statistically) significant effect on job gain expectations, but rather, it is an enhanced set of information about labor-market opportunities transmitted through digital means which explains our findings. In our view it is the value of the information generated by the complementarity between the novelty of the [public/private] information and the higher number of messages received that might explain this relative gain in job expectations. ${ }^{9}$ These results matter because subjective job expectations are a meaningful predictor of subsequent work status (Stephens 2004) and are associated with job search effort (Diagne 2010) and wage growth (Campbell et al. 2007)..$^{10}$

\section{Conclusion}

This study exploits a multi-treatment experimental design implemented as part of the regular (non-experimental) public intermediation system in Peru to investigate the extent to which digital labor-market intermediation influences subjective job gain expectations. Application of a standard difference-in-difference estimator reveals that jobseekers who received digital intermediation based on a large information set increase their before-after job gain expectations relative to the control group. Independent of the information channel, no significant effects were found when labor-market intermediation is based on a restricted (short) set of

\footnotetext{
${ }^{9}$ We acknowledge that evaluating the impacts of each information attribute separately would improve our understanding of the causal channels. In this regard, a nice extension of this paper would consider proxy variables for each information attribute that could be incorporated via interaction terms in equation (1).

${ }^{10}$ In fact, data only from the control group (to isolate the effect from the treatment information) also confirms the positive relationship (0.15) between baseline job gain expectations and future work realizations even after controlling for numerous socio-demographic and labor-market characteristics.
} 
information. An extended analysis about the role of digital labor-market intermediation and the scope of information sets on unemployment spells and job search effort is the next step for us. 


\section{References}

Aker, J. 2010. "Information markets near and far: mobile phones and agricultural markets in Niger," American Economic Journal-Applied Economics, 2(3), 46-59.

Autor, D.H. 2001. "Wiring the labor market," Journal of Economic Perspectives, Vol.15, 25-40.

Campbell, D., A. Carruth, A. Dickerson, and F. Green. 2007. “Job insecurity and wages”, The Economic Journal, 117, pp. 544-566.

Chong, Alberto. 2011. "Development connections: unveiling the impacts of new information technologies," Palgrave MacMillan

Delavande, A. X. Giné, and D. McKenzie. 2011. “Measuring subjective expectations in developing countries: A critical review and new evidence”. Journal of Development Economics 94, 151-163

Diagne, M. 2010. “Information and job search intensity in South Africa”. Mimeo World Bank.

Easterwood, J. C., and S. R. Nutt. 1999. "Inefficiency in analysts' earnings forecasts: Systematic misreaction or systematic optimism?" Journal of Finance 54(5), 1777-97.

Griffin, D., and A. Tversky. 1992. "The weighting evidence and the determinants of confidence", Cognitive Psychology 24(3): 411-35.

Goyal A. 2010. "Information, direct access to farmers, and rural market performance in central India,” American Economic Journal-Applied Economics 2(3), 22-45

Hirshleifer, J., and J. G. Riley. 1992. “The analytics of uncertainty and information”. Cambridge surveys of economic literature. Cambridge ; New York: Cambridge University Press.

Hirshleifer, D., and T. Shumway. 2003. "Good day sunshine: stock returns and the weather." Journal of Finance 58(3), 1009-32.

Jensen, R. 2007. “The digital provide: information (technology), market performance, and welfare in the South Indian fisheries sector," The Quarterly Journal of Economics, Vol.CXX11, Issue 3, 879-924.

Jensen, R. 2010. “The perceived returns to education and the demand for schooling”, The Quarterly Journal of Economics, 125 (2), 515-548

List, J. and I. Rasul. 2010. “Field experiments in labor economics”, NBER WP 16062

Luseno,W, J. McPeak, C. Barrett, G. Getachew, and P. Little. 2003. “The value of climate forecast information for pastoralists: evidence from southern Ethiopia and northern Kenya”, World Development, 31 (9), 1477-1494. 
Manski, Charles, 2004. “Measuring expectations”, Econometrica 72 (5), 1329-1376.

Stephens, M. 2004. "Job loss expectations, realizations and household consumption behaviour", Review of Economics and Statistics, 86 (1), 253-69.

Stinebrickner T. and R. Stinebrickner, 2012. "Learning about academic ability and the college dropout decision”, Journal of Labor Economics, 30(4), 707-748.

Tversky, A. and D. Kahneman.1974. "Judgement under uncertainty: heuristics and biases,” Science, 185, 1124-1131. 
Table 1: Summary Statistics by Treatment Status

Digital Labor-Market Intermediation Program, Lima 2009-2010

Baseline Variables

\section{A. Socio-Demographic}

sex (1=male)

age

years of schooling

single

have children

number of children

migrant

cement floor

cement roof

cement walls

flush toilet

safe water

poverty index

B. Last Labor-Market Experience

worked ever

discouraged worker

montly income (in soles)

hours work per week

had accident insurance

had pension plan

had health insurance

last job matched with skills

C. ICT Usage

use cell phone

cell phone usage for job search

use internet

internet usage for job search

D. Job Gain Expectations

very optimistic

somewhat optimistic

only a little optimistic

do not expect to find a job

$\frac{\text { Treatment Groups }}{\text { Non-digital T1 Digital T2 Digital T3 Control }} \quad$ p-value of F test

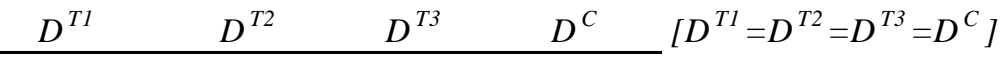

$\begin{array}{ccccc}0.57 & 0.52 & 0.55 & 0.54 & 0.65 \\ 27.04 & 25.33 & 26.27 & 25.55 & 0.02 \\ 12.15 & 12.09 & 12.06 & 11.94 & 0.76 \\ 0.71 & 0.76 & 0.73 & 0.73 & 0.52 \\ 0.32 & 0.26 & 0.32 & 0.26 & 0.22 \\ & & & & \\ 0.27 & 0.29 & 0.26 & 0.25 & 0.75 \\ 0.66 & 0.69 & 0.69 & 0.66 & 0.80 \\ 0.80 & 0.74 & 0.75 & 0.74 & 0.20 \\ 0.91 & 0.88 & 0.89 & 0.89 & 0.64 \\ 0.93 & 0.91 & 0.93 & 0.95 & 0.29 \\ 0.94 & 0.90 & 0.93 & 0.94 & 0.39 \\ 0.06 & -0.12 & -0.01 & 0.02 & 0.66\end{array}$

$\begin{array}{lllll}0.81 & 0.80 & 0.82 & 0.82 & 0.95\end{array}$

$\begin{array}{lllll}0.11 & 0.14 & 0.13 & 0.13 & 0.65\end{array}$

$\begin{array}{lllll}519.82 & 484.97 & 490.60 & 562.00 & 0.60\end{array}$

$\begin{array}{lllll}34.15 & 34.97 & 34.36 & 37.28 & 0.39\end{array}$

$\begin{array}{lllll}0.18 & 0.16 & 0.16 & 0.18 & 0.87\end{array}$

$\begin{array}{lllll}0.25 & 0.26 & 0.21 & 0.22 & 0.66\end{array}$

$\begin{array}{lllll}0.25 & 0.25 & 0.20 & 0.21 & 0.52\end{array}$

$\begin{array}{lllll}0.32 & 0.33 & 0.27 & 0.31 & 0.62\end{array}$

$\begin{array}{lllll}0.95 & 0.95 & 0.96 & 0.97 & 0.43\end{array}$

$\begin{array}{lllll}0.51 & 0.49 & 0.49 & 0.46 & 0.54\end{array}$

$\begin{array}{lllll}0.83 & 0.85 & 0.84 & 0.83 & 0.86\end{array}$

$\begin{array}{lllll}0.60 & 0.62 & 0.61 & 0.62 & 0.91\end{array}$

$\begin{array}{lllll}0.67 & 0.71 & 0.65 & 0.70 & 0.12 \\ 0.29 & 0.24 & 0.30 & 0.25\end{array}$

$\begin{array}{lllll}0.29 & 0.24 & 0.30 & 0.25 & 0.21\end{array}$

$\begin{array}{lllll}0.04 & 0.04 & 0.05 & 0.05 & 0.78\end{array}$

$\begin{array}{lllll}0.00 & 0.01 & 0.00 & 0.00 & 0.86\end{array}$

$\begin{array}{lllll}\boldsymbol{N} & 345 & 188 & 303 & 354\end{array}$

Notes: The test of equal means for the experimental sample is based on a regression with treatment indicators on the right-hand side $D^{T 1}$ refers to the short-non-digital treatmeng group, $D^{T 2}$ to the short-digital treatment group, $D^{T 3}$ to the enhance-digital treatment group, and $D^{T 4}$ to the control group. 


\section{Table 2: Impacts of digital labor market intermediation on job gain expectations}

Labor-Market Intermediation Program, Lima 2009-2010

Dependent var: expect $t_{t+1}-\operatorname{expect}_{t}$

Non-digital treatment $\left(\mathrm{D}^{T 1}\right)$

short-digital treatment $\left(\mathrm{D}^{\mathrm{T} 2}\right)$

enhance-digital treatment $\left(D^{T 3}\right)$

age

male

migrant

single

years of schooling

has children

number of children

poverty index

worked ever

discouraged worker

had accident insurance

had pension plan

had health insurance

had no formal contract

last job matched with skills
(1)

(2)

(3)

(4)

$\begin{array}{cccc}0.015 & 0.032 & 0.035 & 0.037 \\ (0.070) & (0.071) & (0.072) & (0.103)\end{array}$

0.026

0.037

0.035

$-0.006$

(0.084)

(0.085)

$0.144 * *$

$0.154 * *$

(0.073)

(0.072)

$-0.007$

(0.004)

$----$

$-0.029$

---

(0.055)

----

0.039

(0.066)

----

0.078

$--$

(0.098)

--- $\quad-0.002$

---

(0.011)

$---$

0.045

$---$

$-$

(0.0135)

---

0.036

$---$

(0.072)

$---$

0.009

$---$

(0.016)

--- ---

n----

---- ----

--- ----

--- ----

$---$

$---$

$---$

$---$

----

$---$

$---$

$----$

$---$

$--$

---

---

$---\quad---$

--- ---
(0.085)

(0.104)

$0.173 * *$

$0.179 * *$

(0.074)

(0.077)

$-0.008$

$-0.008$

(0.005)

$-0.037$

(0.006)

(0.056)

$-0.055$

0.034

(0.059)

(0.067)

0.034

0.076

(0.072)

(0.098)

0.131

$-0.003$

(0.098)

(0.011)

0.000

0.064

(0.011)

0.083

0.031

(0.136)

(0.076)

0.033

0.007

(0.069)

0.014

(0.001)

(0.023)

$-0.021$

(0.090)

$-0.034$

(0.096)

0.005

(0.068)

$-0.038$

(0.101)

0.181

(0.155)

$-0.114$

(0.156)

$-0.041$

(0.081)

0.083

(0.067)
0.005

(0.096)

$-0.032$

(0.139)

0.211

(0.188)

$-0.090$

(0.178)

$-0.006$

(0.086)

0.070

(0.078)
(0.141)

\begin{tabular}{lcccc}
\hline$R^{2}$ & 0.01 & 0.02 & 0.04 & 0.148 \\
$N$ & 386 & 386 & 386 & 386 \\
\hline
\end{tabular}

Notes: Standard errrors in parenthes is. Estimates based on a parametric differences-in-difference estimator. $D^{T 1}$ refers to the short-non-digital treatmeng group, $D^{T 2}$ to the short-digital treatment group, and $D^{T 3}$ to the enhace-digital treatment group. Base category is the control group. Column (4) includes date fixed effects and clustered standard errors by day. The estimation sample is based on unemployed individuals before and after the intervention. 